\title{
Mirror, mirror: The science
}

\section{BOOK TITLE:}

Seamless leadership: Universal lessons from South Africa

\section{BOOK COVER:}

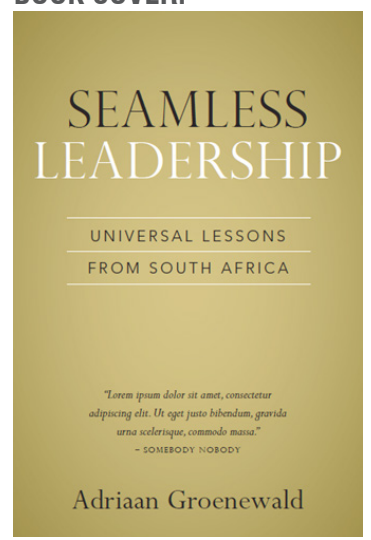

AUTHOR:

Adriaan Groenewald

\section{ISBN:}

9781868426461 (softcover); 9781868426478 (ebook)

\section{PUBLISHER:}

Jonathan Ball, Cape Town; ZAR250 (softcover), USD18 (ebook)

\section{PUBLISHED:}

2015

\section{REVIEW TITLE:}

Mirror, mirror: The science

\section{REVIEWER:}

lain Edwards

\section{EMAIL:}

edwardsl@gibs.co.za

\section{AFFILIATION:}

Gordon Institute of Business Science, University of Pretoria, Johannesburg, South Africa

\section{POSTAL ADDRESS:}

GIBS, P0 Box 787602, Sandton

2146, South Africa

\section{HOW TO CITE:}

Edwards I. Mirror, mirror: The science. S Afr J Sci. 2015;111(9/10), Art. \#a0119, 2 pages. http://dx.doi. org/10.17159/sajs.2015/a0119

\section{(c) 2015. The Author(s).} Published under a Creative Commons Attribution Licence.
Globally, it's a time of asymmetry, instability, volatility and also terror. In this age of uncertainty, much public debate and scholarly enquiry focuses on serious informed reflection on this all too complex issue. There are big books on strategy, international relations, political economy, and ultimately, power. Titles are indicative: Capitalism in the 21st Century, Governance and the World Order in the 21st Century, The End of Certainty, The End of Power, The Locust and the Bee: Predators and Creators in Capitalism's Future and Why Nations Fail. Whilst the popularity of celebrity autobiographies and exposés plummet, quality contemporary autobiographies, memoirs and biographies of properly so prominent public figures - leaders - continue to attract huge readerships. And this really is the crux of so much informed public discussion: it is all about leaders and leadership. So emerge scholarly works such as For the Common Good: The Ethics of Leadership in the 21st Century, The Myth of the Strong Leader and Transforming Leadership. The aspirational self-help book market is booming, particularly in its business leadership, spiritual and strategy genres. Recent titles are illustrative: How Organizations Develop Activists, Radical Management, ServantLeadership, Transformational Leadership, Transforming Leaders into Progress Makers, and so forth.

Groenewald is a South African leadership analyst and consultant. Seamless Leadership is firmly within the latter category of book, but his wide-ranging and confidently strong and ambitious claims are such that the work inevitably ranges into fields covered by the former genres as well. The book has its origins in 2010 when Ellis Mnyandu, the editor of the Business Report (Independent Newspapers' weekday daily financial supplement) and Groenewald sought a means to 'foster a national conversation on leadership' (p.ix). Soon Groenewald was interviewing leaders, largely from within big business but also politicians and sportspeople. Groenewald's interviews became the core of his biweekly Business Report features on leadership. As Mnyandu writes in his Foreword, their mutual understanding was that 'South Africa's legacy is about nothing else but leadership', and in the interviews - and now in this book - Groenewald provides 'a mirror through which the current generation of South African leaders can look at themselves...' ( $p$. ix and $x$ ). The book comprises 18 thematically organised chapters, each with insights and sometimes brief edited transcripts of interviews with one or more South African leaders, plus brief pieces on two US leaders. Chapter titles begin with the 'Seamless Leadership' catchphrase, for example, Chapter 16 is entitled 'Seamless leader attitude to difficulties and leading in difficult times with discussion on Hlengani Mathebula, Gary Crittenden and Gary Player'.

Based on his long experience, and most particularly through these interviews, Groenewald makes a singularly bold statement, which is the key to this book:
So what is the destiny that South Africa must and will fulfil? When destiny and timing collide there is no stopping the movement that will explode. Nelson Mandela is a fitting example of this principle. The collision of his destiny and timing caused an explosion that resulted in a global phenomenon. Our destiny is to bring to the attention of the world that brand of leadership it so badly craves and needs [my emphasis]. Collectively leaders of this and other generations have failed the people of this planet. Followers are disillusioned - and when a beacon of hope for better leadership is held up we gravitate towards it as the entire globe gravitates towards Mandela or to the memory and feelings his leadership brought. The level of gravitation towards Nelson Mandela is a direct reflection of the hunger the world has for better leadership, and we are clearly very hungry! (p.8-9)

To back up this assertion, Groenewald spends much effort in defining his science of seamless leadership and seamless society (p.89). There appears to be four key components, which are developed as the chapters progress. First is the SiPCOM Experience, for which it is important to quote Groenewald in full summary:
..the SiPCOM Experience...captures the truth that all visitors to this planet continually experience Situations (experiences); People (relationships); Choices (decisions); Obstacles (or challenges); and Movement (growth, development). We cannot escape the SiPCOM experience! And the 'COM' in SiPCOM reminds us that all people have this experience in COMMON. (p.15)

Second is the 'Destiny Chain', which 'is about successfully activating and managing the universal law of movement: "All movement is a process governed by integration of motivation, direction and structure." This is what Seamless Leaders do, often subconsciously.' (p.54) [emphasis in the original]. Then there is LIM, the Leadership Impact Model, in which all seamless leaders move 'through at least four stages before making a real impact in leaving a lasting legacy'. These four stages, in sequence, are 'understanding and acceptance', 'credible leadership for consistent performance', 'leadership multiplication of legacy' and 'successful handover' (p.138-142). Finally there is what Groenewald considers his 'contribution'. This is the 'universal law of movement' which states that 'all movement is governed by the integration of motivation, direction and structure: nothing moves without the effective blending of these three components'. He proceeds to cite Edward Kieswetter, CEO of Alexander Forbes, as a successful leader able to 'activate this universal law' (p.163).

There are very many basic problems in understanding this perspective. None of Groenewald's nostrums have any known place in science or contemporary social theory. Where Groenewald does introduce and quote from chosen authorities, he all too often fails to introduce them to readers. He quotes William James writing that 'the greatest revolution of our generation (being) the discovery that human beings, by changing the inner attitudes of their minds, can change the outer aspects of their lives' (p.36). Groenewald describes James as 'a pioneering American psychologist and philosopher', but fails to mention that James' lifetime was from 1842 to 1910 . Likewise with 
Dr Gary Hamel (p.67) -we are not told that he is a long-time member of faculty at the prestigious London Business School and ranked by the Wall Street Journal as a world-leading business strategist. These problems are compounded by further issues, none of which are just technical. The book lacks vital scholarly but accessible appendages: footnotes or end notes, citations and references and even an index. And for a work which makes very big claims to global relevance, why is there no evidence of the very large corpus of scholarly work on these issues? From a reputable publisher this is inexcusable. Is this a celebrity book?

There is great dissonance between Groenewald's overall claims and his interview material. Groenewald never makes his choice of interviewees clear. Rarely is it disclosed or even discernible when interviews occurred - which is important. Are the interview transcripts publicly accessible, and if so where? Nor are chapters linked to dated Business Report articles. Of the 38 interviewees mentioned in this book, 25 are white. The majority are corporate private sector figures. Only four are women: Gill Marcus, Mardia van der Walt-Korsten, Terry Volkwyn and Helen Zille - all of whom are white. As he does not explain his choices, it is difficult to suggest other leading figures. But Groenewald's claims regarding South African leaders, leadership and agency, and a global relevance in wider public affairs must surely imply that his interviewee selection must extend far, far further than private sector corporate white men. So there are glaring omissions. Where are the public figures - in the buzzword terms 'thought leaders' or 'shapeshifters': faith leaders, political analysts, public intellectuals, or 'Struggle' leaders turned business people - and in Cyril Ramaphosa's case - turned politicians again? Why are women so under-represented?

Some of the interview material is interesting, but little is significant, and much is very disappointing. All too often Groenewald seems to be imposing intrusive, trite and pseudo-scientific views onto a near Who's Who entry. The respective sections on President Zuma and Brian Dames, neither of which includes any transcript material, are very disappointing. The interview transcript of Helen Zillie is authentic, but hardly revelatory. The section on Amplats CEO Chris Griffiths - who surely holds one of the toughest corporate private sector positions, even in South Africa's tough mining sector - has potential, but is ultimately a lost opportunity to delve into leadership in real adversity. The same can be said for the sections on Sizwe Nxasana, Bheki Sibiya and Herman Mashaba.

Groenewald never analyses Mandela's leadership style, although there is plenty of primary material available. The section on Roelf Meyer barely spans two pages and is inexplicably banal at best. Despite Groenewald's continual stressing of the defining moment of political negotiations, when 'Nelson Mandela rose to the occasion', his treatment of Mandela and Meyer raises serious doubts over the authenticity of the entire project.

It is generally accepted that South Africa has and continues to produce very powerful and globally influential private sector companies. Some of these companies had their roots in the apartheid years, but many others have a later birth and continue this tradition of being well-led and wellrun companies with global reach. The story of why this is so remains to be properly analysed and told. Despite Groenewald's heavy bias towards private sector corporates, readers rarely get even hints as to key features of this larger picture and its global significance. But it is also accepted that such company executives have long shown a marked reluctance in making considered public analysis and comments on wider social, moral and political issues, either concerning South Africa or more globally. This was glaringly apparent during the apartheid years - even during the insurrectionary times of the 1980s - and it remains so to this day. In the contemporary period - amongst the more prominent business leaders to assert their presence in wide public affairs, together with people such as now outgoing Nedbank chairperson Ruel Khoza and businessman and Free Market Foundation chairperson Herman Mashaba - is Australianborn Mark Cutifani. As Anglo American's head, Cutifani is consistently making considered and trenchant public critiques of the South African government's economic and developmental policies and decision-making and managerial competencies. Cutifani provides vital glimpses into his leadership style: no front office door or designated parking places, no ties and no 'Sir' or 'Meneer'. All this is so refreshingly different from the vanity and peremptoriness which all too easily and quickly afflicts many in high private or public leadership positions. Yet the section on Cutifani is as weak as that on Mashaba. Groenewald is just not looking bravely enough.

Finally, this book is all about successes, often despite tremendous adversity. Where is the discussion and deep 'mirror, mirror' reflections on moral courage, where suffering is an implicit consequence of principled and public bravery? We can think of M.K. Gandhi, Nelson Mandela, and Rev. Beyers Naudé. But where is leadership and moral courage now? Where are the stories of failed leadership, and what lessons can we learn from these? Groenewald has much to say on morality, and tells us often how failure can be the forge on which character is deepened. But leaving matters at the level of aphorism trivialises the importance of the point. Both Gill Marcus, who when interviewed was Governor of the SA Reserve Bank, and Kieswetter raise and stress the important, but still unrecognised, issue of a greater common good in South Africa. Groenewald hardly sees it.

Asking big questions is not only vital for interviewers, but is also an essential responsibility of leaders. As South Africans celebrated various 20th and 25th anniversaries (of the events throughout February 1990 and in 1994) and commemorated the death of Mandela, various influential voices - many with impeccable anti-apartheid and pro-democracy backgrounds sounded notes of caution and warning. In essence their view is that South Africans have yet to ask and address key and difficult questions - including confronting the Mandela cult. Failure to ask difficult questions to which there are no easy answers is the defining point of contemporary South African leadership. South Africans have something to export to a "hungry world'. But this does not involve turning hardworking, determined and courageous South Africans into celebrity name-drops in pursuit of making an unsustainable global point. This must surely be a new pinnacle in delusionary special-case exceptionalism that all too many South Africans, of all political persuasions, are prone to vainly and delightedly bask in, which is precisely that which must be jettisoned. When will South Africans take a good look at themselves? If there are export quality 'universal lessons from South Africa', these are neither evangelical nor messianic messages of inspiration. South Africa is a primary example of how not to develop a post Cold War post-conflict late developing constitutional democracy. Seamless Leadership is hocus-pocus. The mirror is cracked. 